\title{
The Characterisation and Water Equivalency of Rhizophora Spp. Particleboard Bonded with Soy Protein
}

\author{
Nor Ain Rabaiee ${ }^{\mathrm{a}, *}$, Mohd Zahri Abdul Aziz ${ }^{\mathrm{b}}$ and Rokiah Hashim ${ }^{\mathrm{c}}$ \\ ${ }^{a}$ Department of Radiology, Kulliyyah of Medicine, International Islamic University \\ Malaysia,25200 Kuantan, Pahang, Malaysia \\ ${ }^{b}$ Advanced Medical and Dental Institute, Universiti Sains Malaysia, Bertam, Pulau Pinang, \\ Malaysia \\ ${ }^{c}$ School of Industrial Technology, Universiti Sains Malaysia, Minden, Pulau Pinang, \\ Malaysia
}

\begin{abstract}
The objective of this study was to explore the potential of particleboard made from a type of mangrove hardwood, i.e. Rhizophora spp., bonded with soy protein, and evaluate its suitability as a waterequivalent material. First, the bark of the raw hardwood was removed from its trunk prior to the grinding process. Next, three particleboards were fabricated with different percentages of soy protein $(0 \%, 8 \%$, and $16 \%)$. The fabricated particleboards were each characterised for their density, mechanical properties, effective atomic number, morphological structure, elemental composition and probability of photon interaction. The dimensional stability of each fabricated particleboard was evaluated according to the Japanese Industrial Standard (JIS) A 5908, Type-8, while the other properties were compared with that of the standard water phantom. There were improvements shown by the fabricated particleboards with $8 \%$ and $16 \%$ soy protein, in terms of dimensional stability. The morphological images also revealed that the particleboards bonded with $8 \%$ and $16 \%$ soy protein, have better contact between the particles, compared to the one bonded with $0 \%$ soy protein. The elemental analysis, effective atomic number, and probability of photon interaction of the fabricated phantom showed identical results with that of the standard water phantom. Based on the findings of this study, the Rhizophora spp. particleboard bonded with soy protein has opened up possibilities for another potential alternative of solid phantom material as water-equivalent material.
\end{abstract}

Keywords: Photon Interaction, Rhizophora Spp., Water Equivalent Material.

\section{Introduction}

The tropical mangrove trees, i.e. Rhizophora spp., are abundant and can be easily found in the tropical and subtropical coastal regions. This species was mainly harvested to produce firewood, charcoals, newspapers and cardboards [1]. There were several studies conducted on the Rhizophora spp. wood, which resulted in comparable mass attenuation coefficients with that of water [2-4].

The dosimetric phantom commonly used for quality assurance in radiotherapy is the standard water phantom. It is preferred due to its availability, and that it closely mimics the radiation absorption and scattering properties of the soft tissues [5]. However, it is not always practical to handle a large amount of water (in the form of liquid) all at the same time. These lead to the introduction of solid

\footnotetext{
* Corresponding author.

E-mail address: norainrabaiee@iium.edu.my
}

Manuscript History:

Received 19 March, 2021, Revised 20 April, 2021, Accepted 20 April, 2021, Published 30 April, 2021

e-ISSN: 2289-7771

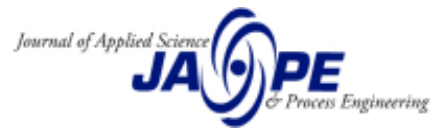


phantom materials, e.g. Perspex, polystyrene and Teflon. Even though these commercial solid phantoms were found to be considerably popular for dosimetric application, they are laborious, expensive and failed to provide good agreement with that of water, at low and high energy range [6].

Material has been suggested as a dosimetric phantom with comparable effective atomic number, electron density and mass density with that of a water phantom [5]. Previous literature has found that the Rhizophora spp. offers comparable dosimetric properties with the other commercial solid phantom materials [7-9]. However, the low dimensional density of the binderless Rhizophora spp. particleboard will affect its performance after a long period. Thus, it was recommended that adhesive should be added to expand its performance, and at the same time able to provide comparable dosimetric properties.

The use of formaldehyde-based adhesives on particleboards are common in the industry, due to their excellent water resistance characteristic [10]. However, formaldehyde was recognised as a human carcinogen by the International Agency for Research on Cancer (IARC) [11]. For this concern, a natural adhesive can be used to improve the performance of this particleboard.

Soy protein has been used on particleboards since the early 20th century [12], as it performed well as an adhesive and thus, successfully reduce the usage of formaldehyde. The natural chemical structure of the soy protein leads to the extensive usage of this adhesive for interior fitting [13].

For the time being, there are limited studies on soy protein as an adhesive, especially in the construction of phantoms for medical application. Thus, this study was conducted to evaluate the suitability of the Rhizophora spp. particleboard bonded with soy protein, as water equivalent materials for the dosimetric application.

\section{Materials and methods}

\subsection{Fabrication of particleboard}

The trunks of Rhizophora spp. (Figure 1) were harvested from the Forestry Department of the Matang Mangrove Forest Reserve, Kuala Sepetang, Perak, Malaysia, and prepared based on a previous study [3]. A surface planer machine (Model HP-20, Holytek, Taichung, Taiwan) was used to cut the trunks into smaller chips, and a grinder machine was used to further grind the chips into a much smaller particle size. Next, three particleboards were fabricated with different percentages of soy protein $(0 \%$, $8 \%$ and $16 \%$ ). For every particleboard, a total of $20 \%$ of distilled water was sprayed onto the mixture during fabrication, to obtain a homogeneous and stronger bond based on the previous study [14].

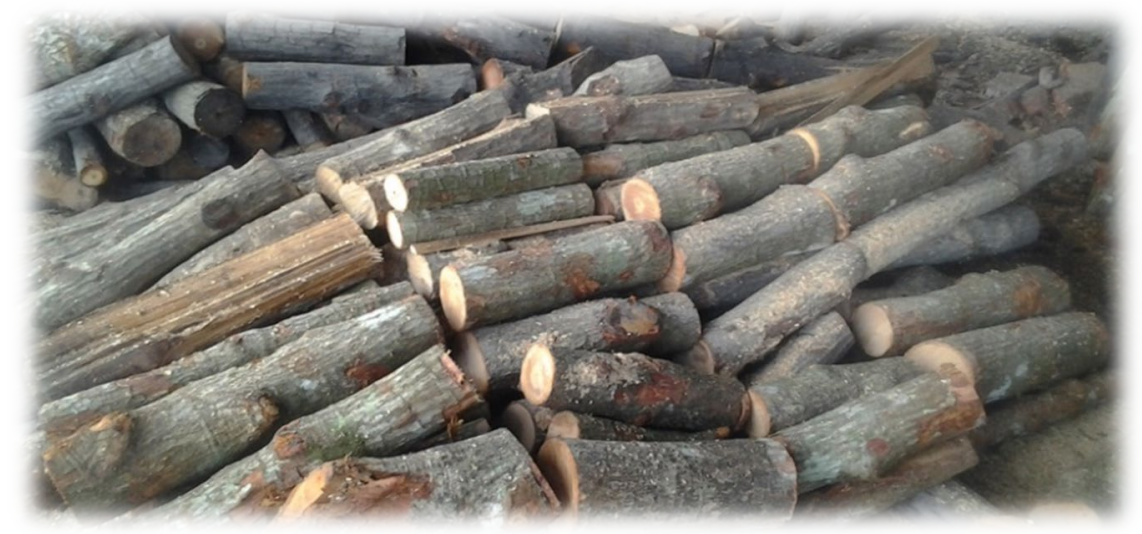

Figure 1. Rhizophora spp.'s trunks harvested from Kuala Sepetang, Perak, Malaysia 


\subsection{Mechanical and physical measurement}

The mechanical and physical properties of the Rhizophora spp. particleboard bonded with soy protein includes, the internal bond strength, water absorption, thickness swelling and density were study. The entire studies were carried out according to the Japanese Industrial Standard (JIS) A 5908, Type-8 [14]. Each sample was prepared into the $5 \times 5 \mathrm{~cm}^{2}$ dimension. A testing system (Model UTM-5582, Instron, Massachusetts, USA) was used to measure the internal bond strength of each sample. Meanwhile, the water absorption and thickness swelling were conducted simultaneously, by immersing the samples in distilled water for $24 \mathrm{~h}$.

Meanwhile, the unknown density of each fabricated particleboard was determined based on the CT number achieved from the images obtained using the 16 slices CT scanner (Toshiba Medical System, Canada). The fabricated particleboards that were cut into the $5 \times 5 \mathrm{~cm}^{2}$ dimension, were scanned together with the electron density phantom (Model 062, CIRS Inc., Virginia, USA), which contains various materials with a known density. A standard abdomen protocol, $120 \mathrm{kVp}, 100 \mathrm{mAs}$ and $3 \mathrm{~mm}$ slice thickness were applied for the scanning procedure.

The CT scanner provides an image in pixel value called the CT number or a Hounsfield Unit (HU). The HU value is defined as the attenuation of the materials in each pixel of a transverse image. The CT number of selected materials on both the electron density phantom and particleboards were measured. The average density of each fabricated particleboard sample was determined from the calibration curve between the CT number and density of known materials, as in Figure 2.

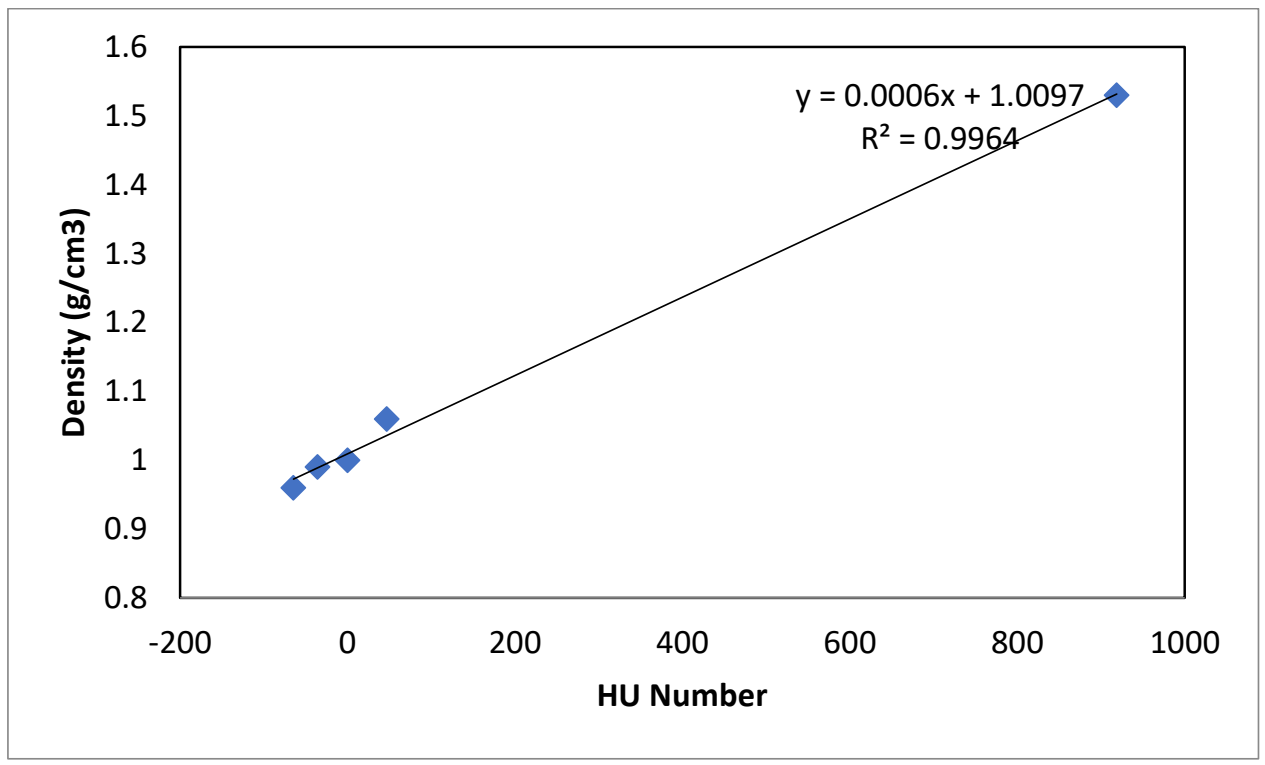

Figure 2. CT calibration curve for density and electron density of adipose tissue, breast tissue, water, muscle and dense bone (listing from left to right).

\subsection{Morphological study}

The morphological study of the fabricated particleboards related to the binding quality of soy protein was carried out using a Field Emission Scanning Electron Microscope (FESEM) (VERIOS 460L, FEI, Oregon, USA). The FESEM can investigate the morphological properties of the fabricated particleboards, up to 40,000 times magnification. The preparation of the samples was conducted by coating each sample with platinum. This was to enhance the conductivity and prevent the charging of the samples, during the scanning process. 


\subsection{Elemental analysis}

The elemental analysis was carried out using a CHNS/O analyser, to determine the elemental composition of the Rhizophora spp. particleboard bonded with soy protein. A total of $2 \mathrm{mg}$ of each sample was prepared for the measurement. The effective atomic number $\left(Z_{\text {eff }}\right)$ depends on the elemental composition of a material, which was calculated by Mayneord's equation as in Equation 1.

$$
Z_{\text {eff }}=\left\lfloor\sum_{i=1}^{n}\left(\alpha_{i} Z_{i}^{m}\right)\right\rfloor^{1 / m}
$$

where, $\propto_{i}, z_{i}$ are the electron fraction and atomic number of element $i$, while $m$ is 4.9 , which is the experimental coefficient for materials, such as wood, water and human organs.

The electron fraction of the $i$ element is given as in Equation 2 .

$$
\alpha_{i}=\frac{w_{i}\left(\frac{Z_{i}}{A_{i}}\right)}{\sum w_{i}\left(\frac{Z_{i}}{A_{i}}\right)}
$$

where, $W_{i}$ and $A_{i}$ are the fractional weight and atomic mass of the $i$ element, respectively.

\subsection{Probability of photon interaction}

The information on the elemental composition of the fabricated particleboard was useful to determine the probability of photon interaction. The determination of the probability of photon interactions for the Rhizophora spp. particleboard bonded with soy protein, solid water phantom and the water phantom, were conducted for energies in the range of $0.001 \mathrm{MeV}$ to $50.000 \mathrm{MeV}$.

\section{Results and discussions}

\subsection{Mechanical and physical properties}

The mechanical and physical properties of the fabricated particleboards, i.e. internal bond strength, water absorption and thickness swelling, were tested according to the JIS A 5908, Type-8 [14]. The internal bond strength of the fabricated particleboards was illustrated in Figure 3. It can be clearly seen that the internal bond strength improved with increasing percentages of soy protein. All the fabricated particleboards managed to successfully achieve the minimum internal bond strength recommended by the JIS A 5908, Type-8 [14]. 


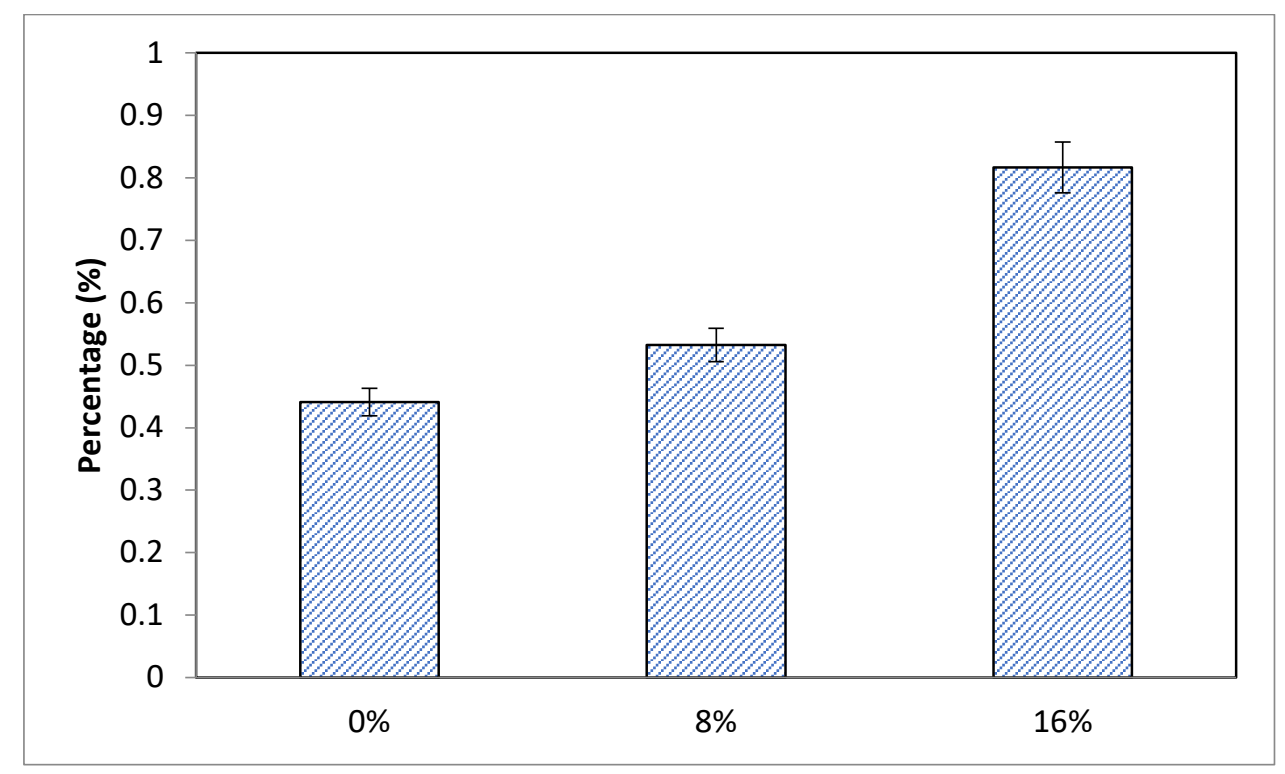

Figure 3. Internal bond strength of the fabricated particleboards. The $0 \%, 8 \%$ and $16 \%$ indicate the percentages of soy protein added to the Rhizophora spp. particleboards.

Meanwhile, the results of water absorption and thickness swelling were illustrated in Figure 4. The results showed that the water absorption varies between $28 \%$ and $53 \%$, while for thickness swelling, the results were found to be in the range of $15 \%$ to $20 \%$. The percentages of water absorption and thickness swelling were reduced, as the percentages of soy protein added to the particleboards increase.

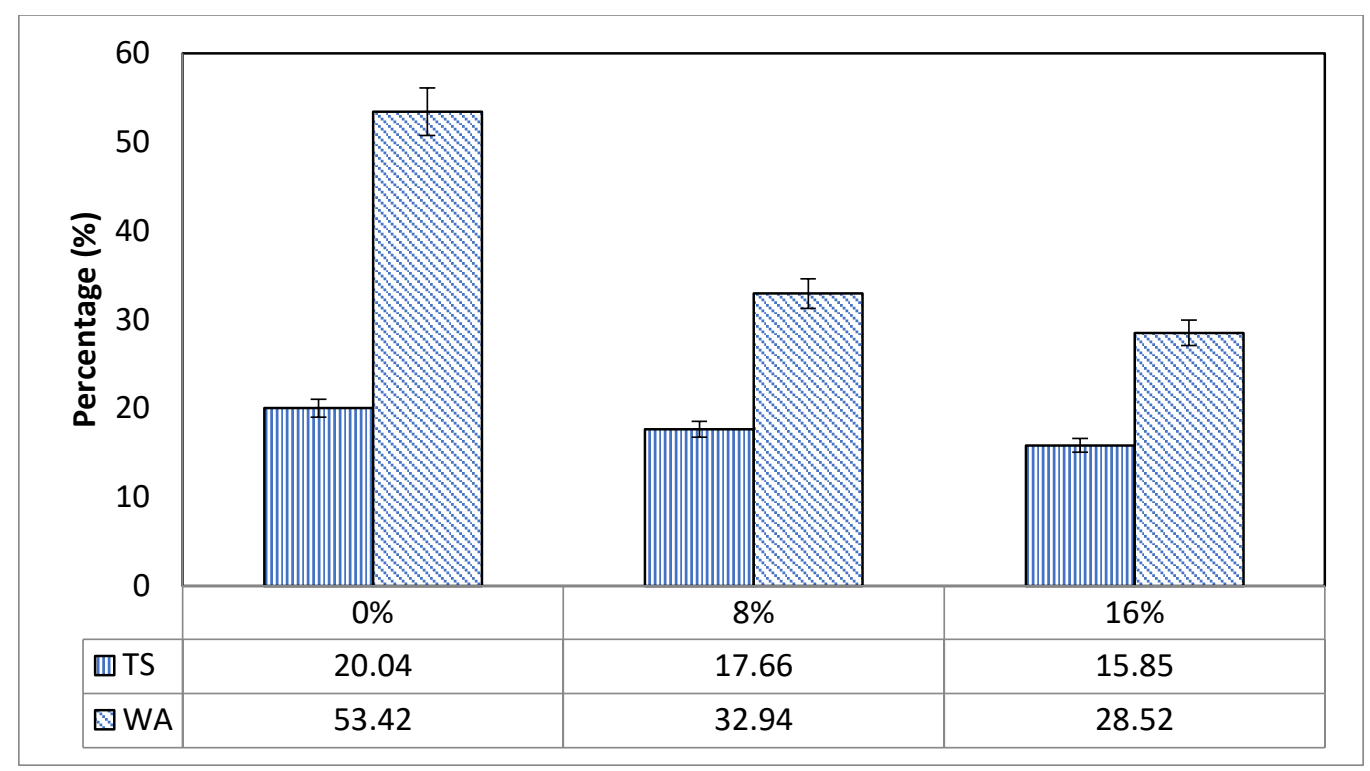

Figure 4. The thickness swelling and water absorption of the Rhizophora spp. particleboards. The $0 \%$, $8 \%$ and $16 \%$ indicate the percentages of soy protein added to the particleboards.

The presence of soy protein as an adhesive in the Rhizophora spp. particleboards caused a reduction in the water absorption and thickness swelling, after $24 \mathrm{~h}$ of immersion. The protein content 
in the soy most likely played a key role in the adhesive properties [15]. It is known that the soy protein possesses a globular shape, and will fold when in contact with water, as the hydrophilic groups were located on the outer surface and the hydrophobic groups on the inside.

It was previously reported that particleboards with higher strength were fabricated with a higher percentage of adhesive [1,7]. Furthermore, the added soy protein has the potential to fill in the gaps and create a more compact structure between the particles and the adhesive [15]. Thus, this improves the dimensional stability of the particleboard.

The average densities of the Rhizophora spp. particleboards bonded with different percentages of soy protein is shown in Table 1 . The results showed that all the particleboards have an identical mass density of either $1.02 \mathrm{~g} / \mathrm{cm}^{3}$ or $1.03 \mathrm{~g} / \mathrm{cm}^{3}$. Previous researchers stated that the ideal material to be used as a dosimetric phantom must have a similar mass density to that of water, which is a well-known standard phantom $[5,15]$. Thus, the results were in good agreement with the density of water, i.e. 1 $\mathrm{g} / \mathrm{cm}^{3}$.

Table 1. The calculated density of the Rhizophora spp. particleboards bonded with soy protein, based on the calibration curve.

\begin{tabular}{|c|c|c|}
\hline Sample & HU number & Density $\left(\mathrm{g} / \mathrm{cm}^{3}\right)$ \\
\hline $\begin{array}{l}\text { Rhizophora spp. particleboard bonded } \\
\text { with } 0 \% \text { soy protein. }\end{array}$ & $25.03 \pm 0.12$ & 1.02 \\
\hline $\begin{array}{l}\text { Rhizophora spp. particleboard bonded } \\
\text { with } 8 \% \text { soy protein. }\end{array}$ & $29.57 \pm 0.25$ & 1.03 \\
\hline $\begin{array}{l}\text { Rhizophora spp. particleboard bonded } \\
\text { with } 16 \% \text { soy protein. }\end{array}$ & $23.17 \pm 0.21$ & 1.02 \\
\hline
\end{tabular}

\subsection{Field emission scanning electron microscope (FESEM) images}

The FESEM images of the fabricated particleboards at 800 times magnification are shown in Figure 5. It can be observed that the distributions of the Rhizophora spp. particles and the soy protein were homogenous. Increasing the percentage of adhesive may increase the contact area within the particleboard, resulting in a smaller void space, as supported by a previous researcher [16]. Figure 5 (b) and (c) reveal that the melted soy protein ended up covering the void spaces left as in Figure 5 (a). The compression process during the fabrication has highly influenced the structure of the particleboard. Plus, the high pressure applied was effective in reducing the void spaces. 


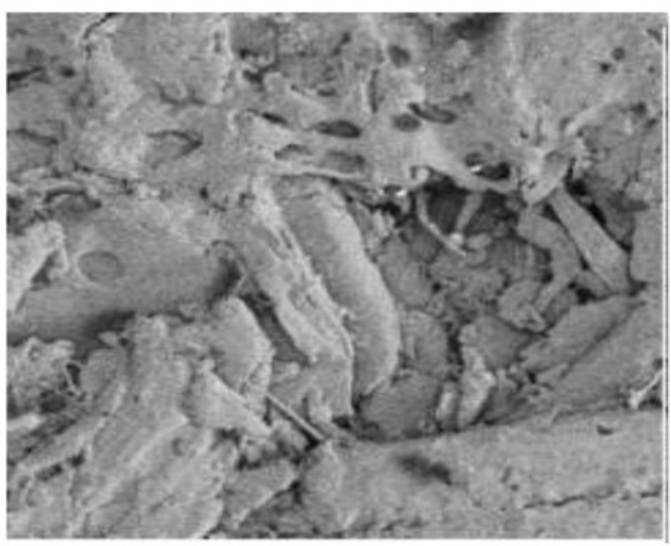

(a)

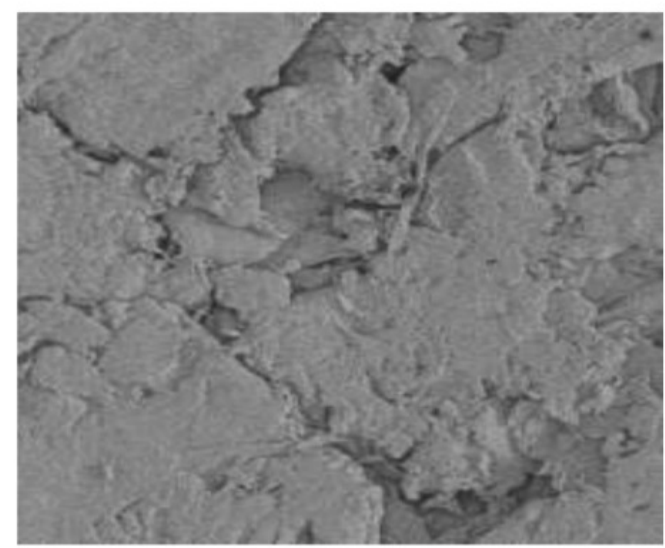

(b)

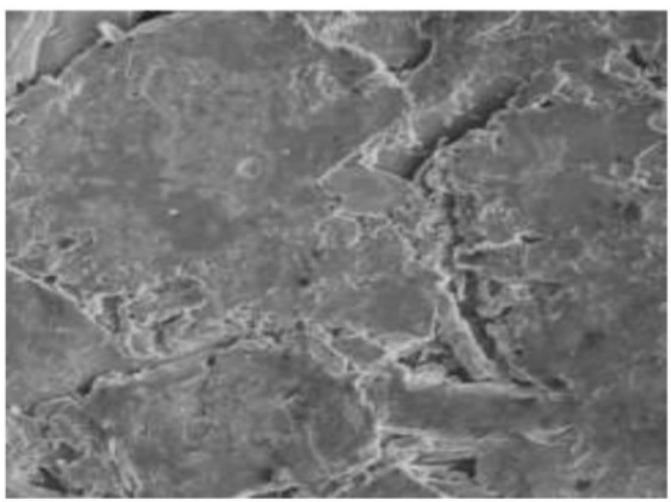

(c)

Figure 5. Micrographs of the Rhizophora spp. particleboards bonded with (a) $0 \%$, (b) $8 \%$ and (c) 16 $\%$ soy protein, at 800 times magnification using a FESEM.

\subsection{Evaluation of elemental composition and $Z_{\text {eff }}$}

The elemental composition of the Rhizophora spp. particleboards bonded with soy protein was analysed using the CHNS/O analyser. Carbon, hydrogen and oxygen are the major elements contained in the human soft tissues. The elements of the fabricated particleboards and several other dosimetric phantoms are shown in Table 2.

Oxygen (48.09 \%) is the most abundant elemental component in the fabricated Rhizophora spp. particleboard bonded with $8 \%$ soy protein, followed by carbon (44.02\%) and hydrogen $(7.00 \%)$ as in Table 2 . The Rhizophora spp. particleboard bonded with $8 \%$ soy protein contains all the major elements that constitute the soft tissue. It also contains the elements that are not available in one of the commercial solid phantom, i.e. polystyrene, with the advantage of having the closest $Z_{\text {eff }}$ value to that of water.

It is important to have information on the elemental composition of the fabricated Rhizophora spp. particleboard. According to Taylan and Osman, a potential water equivalent material should exhibit radiological and atomic properties similar to water [17]. Thus, based on this result, it is expected that the Rhizophora spp. particleboard bonded with $8 \%$ soy protein is also able to provide good properties as a tissue-equivalent material. 
Table 2. Elemental composition and effective atomic number, $Z_{\text {eff }}$ of the Rhizophora spp. particleboards bonded with $0 \%$ and $8 \%$ soy protein, soy protein, water, solid water and polystyrene.

\begin{tabular}{|c|c|c|c|c|c|c|}
\hline Sample & H (\%) & $\mathrm{C}(\%)$ & N (\%) & O (\%) & Others (\%) & $\mathbf{Z}_{\mathrm{eff}}$ \\
\hline $\begin{array}{l}\text { *Rhizophora spp. particleboard with } \\
0 \% \text { soy protein }\end{array}$ & 5.37 & 40.96 & 0.89 & 52.29 & S:0.45 & 7.09 \\
\hline $\begin{array}{l}\text { *Rhizophora spp. particleboard } \\
\text { bonded with } 8 \% \text { soy protein }\end{array}$ & 7.00 & 44.02 & 0.88 & 48.09 & S:0.01 & 7.10 \\
\hline *Soy protein & 5.49 & 48.98 & 8.32 & 37.21 & - & 7.07 \\
\hline${ }^{a}$ Water & 11.16 & - & - & 88.81 & - & 7.42 \\
\hline${ }^{\text {aSolid }}$ water & 9.25 & 62.82 & 1.00 & 17.94 & $\begin{array}{l}\mathrm{Cl}: 0.96 \\
\mathrm{Ca}: 7.95 \\
\mathrm{Br}: 0.03\end{array}$ & - \\
\hline aPolystyrene & 7.74 & 92.26 & - & - & - & 5.69 \\
\hline
\end{tabular}

Note: ${ }^{a}[5] ;{ }^{*}$ current study.

\subsection{Probability of photon interaction}

Further studies on the Rhizophora spp. particleboard bonded with $8 \%$ soy protein were conducted, to determine the probability of photon interaction as compared with the water phantom. This study was conducted based on the previous information of the elemental composition in Table 2. Figure 6 illustrated the basic photon interaction that is important in radiotherapy, at an energy range of between $0.001 \mathrm{MeV}$ and $50.000 \mathrm{MeV}$. Identical curves were observed in two different media, i.e. the Rhizophora spp. particleboard and water, for different photon interactions, i.e. photoelectric absorption, Compton scattering and pair production.

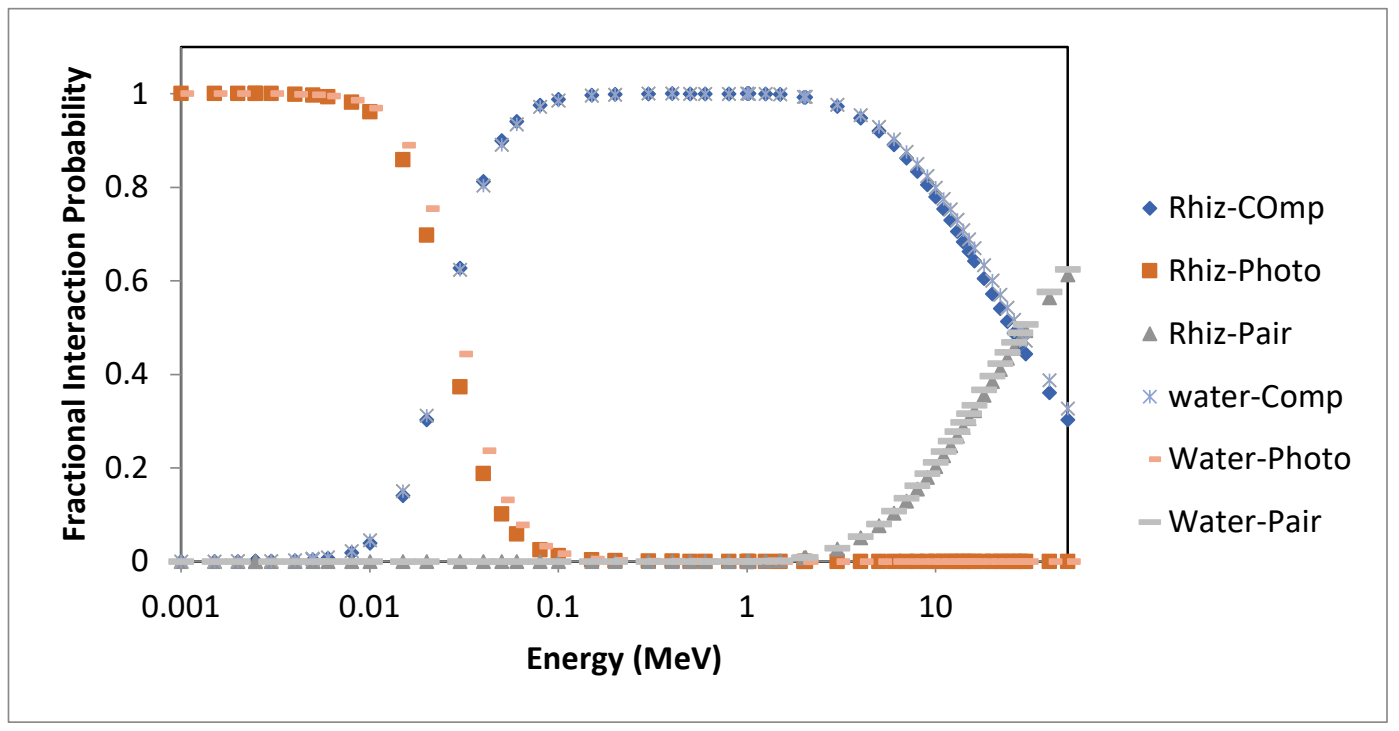

Figure 6. The probability of photon interactions in the Rhizophora spp. particleboard bonded with $8 \%$ soy protein and water phantom.

Generally, at lower energy, the probability of photoelectric interaction is very high and thus, useful for diagnostic imaging. As the energy of the photons increase, the probability of the photoelectric interaction drops rapidly, while the Compton interaction becomes more prominent, as illustrated in Figure 5. 
A similar study was conducted by comparing several materials such as polymethyl methacrylate (PMMA), polystyrene, blood liquid, soft tissue and water [18]. They found the absorption of blood liquid, soft tissue and water are similar at high photon energy. However, PMMA did not correspond well with other materials due to its density.

\section{Conclusions}

The suitability of the Rhizophora spp. particleboard bonded with soy protein as a dosimetric phantom has been evaluated in this study. The density of the fabricated particleboard is comparable to that of the water phantom. The soy protein successfully acts as an adhesive, providing better contact between the Rhizophora spp. particles, and thus, improving the phantom's dimensional stability. The elemental study using the CHNS/O analyser showed that the Rhizophora spp. particleboard bonded with soy protein contains all the major elements that constitute the soft tissue. The Rhizophora spp. particleboard bonded with $8 \%$ soy protein, has been shown to produce identical photon interactions as the water phantom, at the energy range of between $0.001 \mathrm{MeV}$ and $50.000 \mathrm{MeV}$. In conclusion, the fabricated particleboard has the potential as an alternative dosimetry phantom material, able to closely mimic the properties of the standard water phantom.

\section{Acknowledgements}

The authors would like to express their appreciation to the International Islamic University Malaysia, School of Industrial Technology, Universiti Sains Malaysia (USM) and Cluster of Oncological and Radiological Sciences, Advanced Medical and Dental Institute (AMDI), Bertam, Pulau Pinang, Malaysia. The authors would also like to thank the Ministry of Higher Education, Malaysia, for the research funding, i.e. the Fundamental Research Grants Scheme (FRGS) 203/CIPPT/6711341.

\section{References}

[1] Abuarra, A., Hashim, R., Bauk, S., Kandaiya, S., \& Tousi, E. T. (2014). Fabrication and characterization of gum Arabic bonded Rhizophora spp. particleboards. Materials \& Design,60, 108-115. https://doi.org/10.1016/j.matdes.2014.03.032

[2] Tousi, E. T., Bauk, S., Hashim, R., Jaafar, M. S., Abuarra, A., Aldroobi, K. S. A., \& Al-Jarrah, A. M. (2014). Measurement of mass attenuation coefficients of Eremurus-Rhizophora spp. particleboards for X-ray in the 16.63-25.30 keV energy range. Radiation Physics and Chemistry, 103, 119-125. https://doi.org/10.1016/j.radphyschem.2014.03.011

[3] Shakhreet, B. Z., Bauk, S., \& Shukri, A. (2013). Mass attenuation coefficients of fabricated Rhizophora spp. particleboard for the 15.77-25.27 keV range. Am. J. Sci. Ind. Res, 4(1), 89-94. doi:10.5251/ajsir.2013.4.1.89.94

[4] Marashdeh, M. W., Bauk, S., Tajuddin, A. A., \& Hashim, R. (2012). Measurement of mass attenuation coefficients of Rhizophora spp. binderless particleboards in the 16.59-25.26 keV photon energy range and their density profile using x-ray computed tomography. Applied Radiation and Isotopes, 70(4), 656-662. https://doi.org/10.1016/j.apradiso.2012.01.008

[5] Khan, F. M., \& Gibbons, J. P. (2014). Khan's the physics of radiation therapy. Lippincott Williams \& Wilkins. ISBN 978-1-4511-8245-3

[6] Banjade, D. P., Tajuddin, A. A., \& Shukri, A. (2001). A study of Rhizophora spp wood phantom for dosimetric purposes using high-energy photon and electron beams. Applied Radiation and Isotopes, 55(3), 297-302. https://doi.org/10.1016/S0969-8043(01)00057-4

[7] Taghizadeh Tousi, E., Hashim, R., Bauk, S., Suhaimi Jaafar, M., Hamdan Abuarra, A. M., Mahmoud AlJarrah, A., ... \& Ali Aldroobi, K. S. (2015). Characterization of the rhizophora particleboard as a tissue- 
equivalent phantom material bonded with bio-based adhesive. Maderas. Ciencia y tecnología, 17(2), 305318. http://dx.doi.org/10.4067/S0718-221X2015005000029

[8] Tajuddin, A. A., Sudin, C. C. W., \& Bradley, D. A. (1996). Radiographic and scattering investigation on the suitability of Rhizophora sp. as tissue-equivalent medium for dosimetric study. Radiation Physics and Chemistry, 47(5), 739-740. https://doi.org/10.1016/0969-806X(95)00052-Y

[9] Bradley, D. A., Tajuddin, A. A., Sudin, C. W. A. C. W., \& Bauk, S. (1991). Photon attenuation studies on tropical hardwoods. International journal of radiation applications and instrumentation. Part A. Applied radiation and isotopes, 42(8), 771-773.1. https://doi.org/10.1016/0883-2889(91)90182-Z

[10] Frihart, C. R., \& Wescott, J. M. (2004). Improved water resistance of bio-based adhesives for wood bonding. In Proceedings of ICECFOP1-1st International Conference on Environmentally-Compatible Forest Products: Fernando Pessoa University, Oporto, Portugal, 22-24 September 2004. Porto, Portugal: Edicoes Universidade Fernando Pessoa, 2004: Pages 293-302.

[11] Bertaud, F., Tapin-Lingua, S., Pizzi, A., Navarrete, P., \& Petit-Conil, M. (2012). Development of green adhesives for fibreboard manufacturing, using tannins and lignin from pulp mill residues. Cellulose Chem. Technol, 46(7-8), 449-455. ISSN 2457-9459

[12] Frihart, C. R., \& Birkeland, M. J. (2014). Soy properties and soy wood adhesives. In Soy-based chemicals and materials (pp. 167-192). American Chemical Society. DOI: 10.1021/bk-2014-1178.ch008

[13] Kumar, R., Choudhary, V., Mishra, S., Varma, I. K., \& Mattiason, B. (2002). Adhesives and plastics based on soy protein products. Industrial crops and products, 16(3), 155-172. https://doi.org/10.1016/S09266690(02)00007-9

[14] Japanese Industrial Standard (JIS). (2003). JIS A-5908. Particleboards, Japanese Standards Association, Tokyo, Japan.

[15] Frihart, C. R., Birkeland, M. J., Allen, A. J., \& Wescott, J. M. (2010). Soy adhesives that can form durable bonds for plywood, laminated wood flooring, and particleboard. In Proceedings of the International Convention of Society of Wood Science and Technology and United Nations Economic Commission for Europe--Timber Committee, October 11-14, 2010, Geneva, Switzerland.[Sl: sn], 2010: 1-13.

[16] Hill, R. F., Brown, S., \& Baldock, C. (2008). Evaluation of the water equivalence of solid phantoms using gamma ray transmission measurements. Radiation Measurements, 43(7), 1258-1264. https://doi.org/10.1016/j.radmeas.2008.01.019

[17] Tuğrul, T., \& Eroğul, O. (2019). Analysis of water-equivalent materials used during irradiation in the clinic with XCOM and BEAMnrc. Journal of Radiation Research and Applied Sciences, 12(1), 455-459. https://doi.org/10.1080/16878507.2019.1708576

[18] Tousi, E. T., Hashim, R., Bauk, S., Jaafar, M. S., Abuarra, A. M. H., \& Ababneh, B. (2014). Some properties of particleboards produced from Rhizophora spp. as a tissue-equivalent phantom material bonded with Eremurus spp. Measurement, 54, 14-21. https://doi.org/10.1016/j.measurement.2014.04.004 